Published by the University of KwaZulu-Natal https://journals.ukzn.ac.za/index.php/JICBE (C) Creative Commons With Attribution (CC-BY) Journal of Inclusive cities and Built environment. Vol. 2 Issue 1

How to cite: B. Wahab and O. Falola. 2022. Vulnerable Households in Flood-prone Communities in Ibadan: Measures to improve their Status within the Inclusive Ibadan City Framework. Conference Proceedings for International Symposium on Inclusive-Cities: Achieving Inclusive Cities Through A Multidisciplinary Approach, 2021 28-30 June. Journal of Inclusive cities and Built environment. Vol. 2 Issue 1, Pg 21-27.

\title{
VULNERABLE HOUSEHOLDS IN FLOOD-PRONE COMMUNITIES IN IBADAN: MEASURES TO IMPROVE THEIR STATUS WITHIN THE INCLUSIVE IBADAN CITY FRAMEWORK
}

\author{
By B. Wahab and O. Falola
}

Published 31 January 2022

\begin{abstract}
Abstract. The number of people affected by climate-related hazards is on the rise, particularly in low- and middleincome countries where rapid urbanization is taking place. The frequency/intensity of flooding is a risk multiplier for the vulnerable groups in many cities. Issues of development and poverty have led more people to live in areas vulnerable to flooding. This paper assesses a range of vulnerabilities with particular focus on households (HHs) living in flood-prone areas.
\end{abstract}

The study assesses the impact of the last major flood disaster in Ibadan on the vulnerable groups (the poor, elderly, children and physically challenged). It investigates how vulnerable $\mathrm{HHs}$ have responded to the post-disaster events. The study finds that $\mathrm{HHs}$ from $56 \%$ of the affected buildings suffered temporary displacement and 207 (7.4\%) of the affected buildings were abandoned with Ibadan South-West LGA recording the highest cases of abandonment $(23 \%)$. There exists a positive correlations between income and period of displacement $(\mathrm{r}=0.26)$ and a significant difference in the period of displacement across income groups. The study reveals disparities in access to relief/recovery items among flood-affected population. Urban dwellers had better access to relief packages than rural dwellers.

The paper calls a shift in policy thrusts from mere distribution of relief items to more inclusive and empowering programmes for the vulnerable groups to mitigate and adapt to flood disasters. The need to build community resilience, protect vulnerable HHs from recurrence of unmitigated flood disasters should be embedded in a programme of actions adopted by the governments at all levels.

KEY WORDS Flood-prone communities, Vulnerable households, Coping mechanisms, Disaster-induced displacement, Inclusive Ibadan City

Bolanle Wahab: Department of Urban and Regional Planning, University of Ibadan, Nigeria. E-mail: bolanle_wahab@yahoo.com Olusegun Falola: Department of Urban and Regional Planning, University of Ibadan, Nigeria 


\section{INTRODUCTION}

Over the past decades, the pattern of floods across all continents has been changing, becoming more frequent, intense, and unpredictable for local communities, particularly as issues of development and poverty have led more people to live in areas vulnerable to flooding (ADPC and UNDP, 2005). As more people crowd into cities, so the effects intensify. As a result, even quite moderate storms produce high flows in rivers because there are more hard surfaces and inadequate drains (Akintola, 1994).

The vulnerability of Nigerian urban centres to flood hazard and disasters has been a subject of increasing academic interest. Certain cities are naturally prone to flooding while others have unwittingly been subjected to vulnerability. Urban areas in Nigeria are particularly vulnerable to flooding due to inadequate capacity of drainage structures; changes to ecosystem through the replacement of natural and absorptive soil cover with concrete; and deforestation of hillsides, which increases the quantity and rate of runoff, and through soil erosion and the silting up of drainage channels (Adedeji et al., 2012).

The impacts of floods on lives and livelihoods and the way agencies and individuals have addressed them are similar in most parts of the world. The effectiveness of agency interventions has, however, always been conditioned by factors specific to the context and circumstances (ALNAP and ProVention, 2008; ADPC and UNDP, 2005).

The impacts of disaster are uneven, and vulnerable groups need special attention. Vulnerable groups often include women and children, ethnic minorities and indigenous groups and the elderly and disabled (Agbola et al., 2009). This arises from differences in income status, culture, gender, location and type of home, and land tenure. A common inequity occurs when the immediate needs of the poor are ignored in the immediate post-disaster period (ALNAP and ProVention, 2008).
The Nigerian government at all levels has done little to assist vulnerable households who have been displaced by flood. As a result of recurrent flooding in the Ibadan region, many residents have been forced to flee their homes. The government has attempted to address the effects of flood disaster, but they have not developed any solutions for addressing the plight of current and future displaced residents. The assumption seems to be that most displacement from disasters is temporary - that when the flood waters recede or rainfall brings an end to drought - people will simply go back home. But there have been no systematic efforts to monitor the extent of displacement, processes of return, or the extent of secondary displacement in cases of sudden-onset natural disasters.

The vulnerable groups have poor or no access to facilities and services (potable water, sanitation, education, health, and communication), live in dangerous and health-threatening (flood-prone) areas of the city owing largely to their exclusion from decision-making and weak urban governance. Schneider et al. (2007) opined that the degree to which a population was vulnerable to hazards was not dependent solely on the exposure to the hazard but also the social, economic, and political factors that influence people and communities. The notion was that, owing to disparities in wealth, socioeconomic status, and housing, some population subgroups (individuals, households, or communities) have a disproportionate exposure to hazards as they have less ability to adapt, cope, or respond (Schneider et al., 2007).

Lavell (2003) affirmed that land use and territorial planning are key factors in flood risk reduction. Population dynamics, diverse demands for location, and the gradual decrease in the availability of safer lands mean it is almost inevitable that humans and human endeavour will be located in potentially dangerous places (Lavell, 2003). As part of the Impoverishment Risks and Reconstruction approach, Cutter et al. (2003) outlines the eight basic risks to which people are subjected by displacement. These are: landlessness, joblessness, homelessness, marginalization, food insecurity, increased morbidity, loss of access to common property resources, and social disarticulation. When people are forced from their known environments, they become separated from the material and cultural resource base upon which they have depended for life as individuals and as communities (Bankoff, 2004).

In recent time, discussion has shifted to living with floods and adapting to their impacts, especially as large-scale floods are becoming common (DEC, 2000a; Kent et al., 2004). However, the challenge of addressing urban floods and reducing urban flood vulnerability has received little attention (Zevenbergen, 2008). This is partly because in the traditional flood management approach, responses to mitigate urban fluvial and coastal flood risks have often been set outside the realm of the urban system (where confined to the catchment level), but also because responses at the city level were predominantly passive, using robust solutions such as urban defences and increasing the capacity of major culverts.

A review of a preparedness programme in Bangladesh shows that vulnerable people have little or no surplus income to invest in the measures that can protect them from flooding although they know what to do (Alam et al., 2007b). The destruction of assets, which function as a buffer, can make people more vulnerable to the next flood (DipECHO, 2004). A study by the International Food Policy Research Institute (IFPRI) (2001) after the 1998 Bangladesh flood found that 55 per cent of households lost assets, equivalent to 16 per cent of their pre-flood total value of assets. In Mozambique, the World Bank noted that during the recovery period, these assets were, in general, not replaced, leaving the households more vulnerable to subsequent disaster episodes (World Bank, 2005b). ALNAP and ProVention (2008) argues that urban dwellers enjoyed favouritism at the distribution of relief items at the expense of rural and peri-urban dwellers.

The forgoing provides the basis for this study. This paper focuses on the challenges of the vulnerable groups living in flood-prone communities. In the 
aftermath of August 26th and July 14th Floods in Ibadan, Nigeria, this paper assesses how the socioeconomic characteristics of vulnerable households affects their response to flood events and recovery from flood impacts. It looks at cases where people are forced to vacate their homes in a seemingly unplanned and disjointed way.

\section{SETTINGS AND METHODS}

The study was carried out in Ibadan, the capital of Oyo State, Nigeria, one of the largest traditional city in Africa (Figure 1). Frequent rainstorms and flooding in Ibadan has made it one of the most vulnerable cities in Nigeria in the recent past. The number of such incidents has been on the increase in the last few years.

This survey-based study used primary and secondary data. Data were recorded over time through field survey. Questionnaire, interview guide, and telephone conversation were adopted for data collection. Households (HHs) living in the 2,270 buildings affected by the August 26th, 2011 flood disaster were the target population. Multistage sampling technique was adopted. A random sample of $1,175(50 \%)$ buildings were selected from the 2,270 flood-affected buildings and copies of household questionnaire were administered on the longest serving $\mathrm{HH}$ in each building. Interview sessions were conducted on flood-displaced persons, landlords associations' chairmen and staffs of the Oyo State Emergency Management Agency (OYOSEMA) and Nigerian Red Cross Society (NRCS). The survey on temporary displacement was conducted between a week and 3 weeks after the disaster's onset in August 26, 2011. Data collection on permanent displacement were collected 12 months after the August 26,2011 flood.
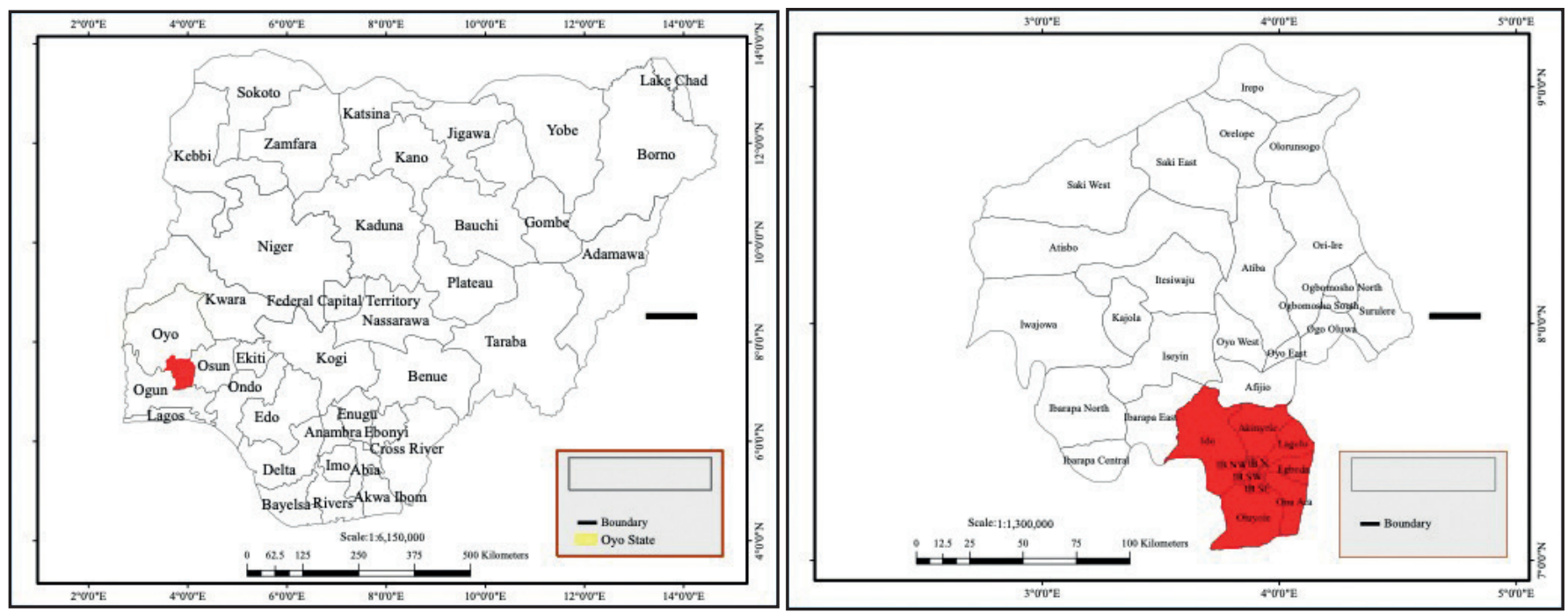

\section{RESULTS AND DISCUSSION}

\subsection{FLOOD-INDUCED DISPLACEMENT OF HOUSEHOLDS}

The Oyo State Task Force on Flood Prevention and Management on September 9, 2011. From the report of the task force, it was declared that 2,105 buildings were washed away and over 100 lives lost (Oyo State Government, 2011). Interview with the officials of NRCS gave a more precise measure of the Ibadan floods in terms of casualty. NRCS believes that no fewer than 102 people died in the disaster. No specific statistic or figure has been given on the number of displaced persons.

Accessibility status of 955 (84\%) buildings were determined during the field survey. Results show that 584 (51.5\%) buildings were accessible while $33 \%$ were inaccessible. The period of inaccessibility varied from days to over a week. Although, considerable number of $\mathrm{HHs}$ were yet to return to their homes, 220 respondents (19.4\%) claimed their homes were inaccessible for 1-2 days. Houses representing $10 \%, 2 \%$ and $2.3 \%$ were not accessible for 3-4 days, 5-6 days and above 6 days respectively.

Households from 634 buildings (56\%) suffered temporary displacement and were forced to relocate till the water receded while $40.6 \%$ were able to manage flood impact without having to leave their houses. More than forty percent (42.1\%) of the displaced $\mathrm{HHs}$ were displaced for at least a week $(26.4 \%, 15.1 \%$ and $39.6 \%$ for 15 days to 1 month, $1-2$ weeks, and less than a week respectively); $40 \%$ stayed away from their homes for less than a week; $20 \%$ were displaced for over a months; $46 \%$ displaced for more than two weeks; and $6 \%$ left their homes for over six months. The period of displacement depended on the level of impact of flood on the affected houses/HHs, availability of alternative place for the displaced as well as availability of adequate resources to embark on clean-up. Majority of the displaced HHs returned to their homes. However, some buildings were abandoned, demolished or collapsed. 
Most $(84 \%)$ of the flood-displaced HHs planned to return to their homes. Respondents from household survey gave their opinions about probable resettlement and forced relocation; $71 \%$ of which said they would accept any resettlement scheme from the government while $23 \%$ were not ready to relocate. Reasons were given for their choices. Almost all (54\%) of HHs that were ready to be relocated said their decision was based solely on avoiding future flood disasters. Some of them went further to explain that they were still living in floodable areas because they currently had no better alternatives.

On the other hand, majority $(52 \%)$ of those that were not in support of relocation claimed that their places of work and sources of income were tied to their present location. These included school proprietors, church/mosque owners and business owners. The majority $(49 \%)$ of the affected $\mathrm{HHs}$ support that people living in areas prone to flood hazards should relocate.

Households whose homes were completely destroyed or rendered uninhabitable owing to flood impacts (and who survived), some HHs whose homes were partially damaged (and showed signs of collapse and related risk to residents) and those whose buildings were demolished by government for building on flood plain and stream setback were regarded to be permanently displaced. There were situations when people could no longer cope with the 'threat to life' posed by flood hazards, they eventually abandoned their dwellings for safer place (see plates 1 and 2 ).

\section{Plate 1: Abandoned building at Agbowo, Ibadan North LGA}

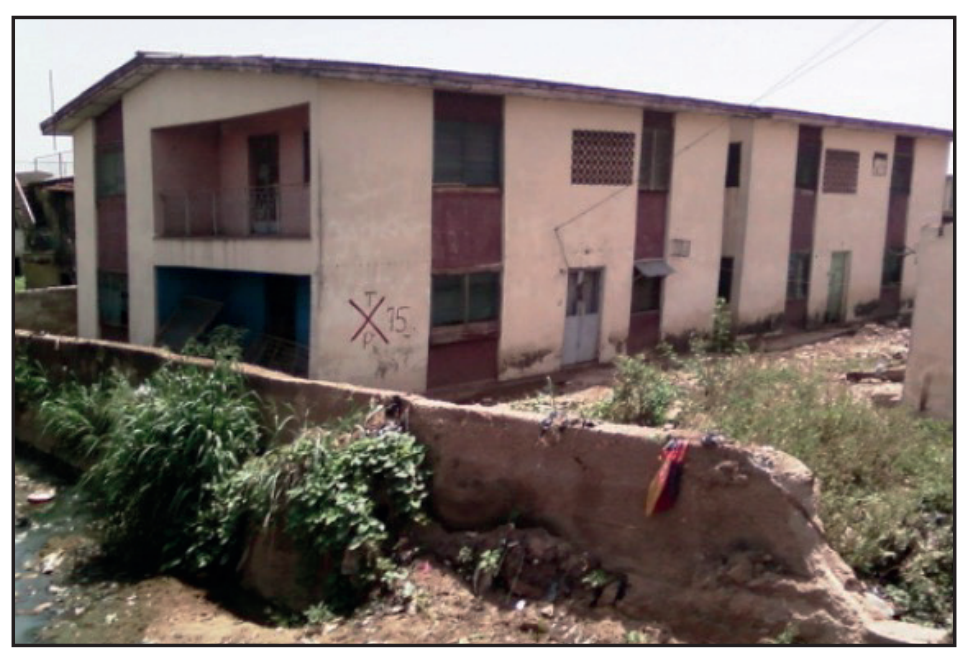

Source: Field Survey, 2012

Plate 2: Abandoned building at Odo-Ona Area in Ibadan South-West LGA

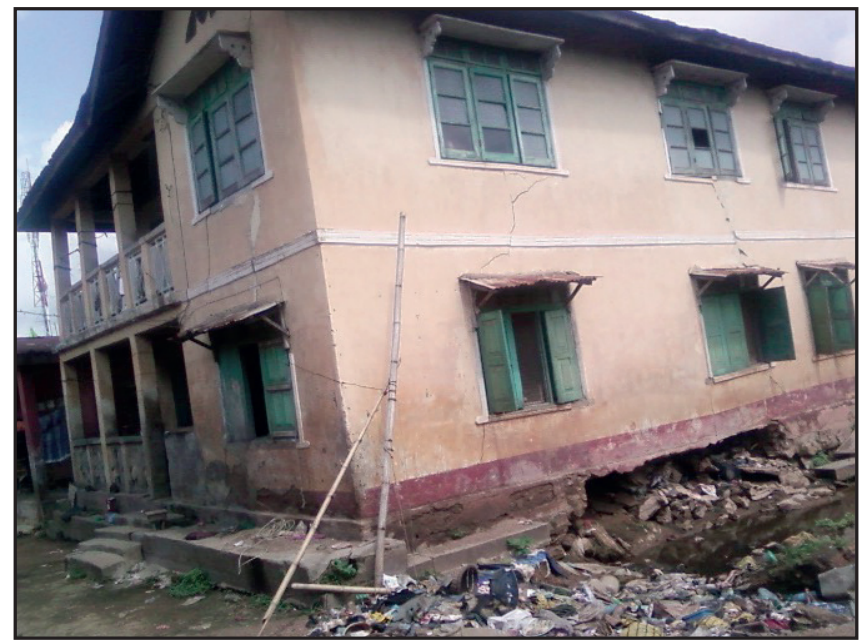

Source: Field Survey, 2012
There were certain cases where $\mathrm{HHs}$ did not return homes primarily because human lives were lost in those houses. A good example is the case of an abandoned building at Agbowo area, where every member of the HHs was submerged in flood water and died. The house has been locked-up since then. The same situation was recorded in Oke-Ayo Area in Ibadan South-West LG where another house has been abandoned solely because a $\mathrm{HH}$ lost six members (mostly children) to flood disaster. The sole survivor of the $\mathrm{HH}$, the mother, who could not withstand the agony of seeing the house in which she lost six souls in a day any longer, was reported to have permanently moved to llesa, Osun State.

A total of 207 (7.4\%) of the affected buildings were abandoned. Ibadan South-West LGA has the highest number if abandoned buildings. The average number of $\mathrm{HHs}$ per flood-affected building was $3 \mathrm{HHs}$. The total number of permanently displaced households can be estimated as average $\mathrm{HH}$ per building multiply by number abandoned buildings (i.e., $3 \times 207=621 \mathrm{HHs}$ ). Therefore, it can be concluded that 621 households have been permanently displaced. Similarly, the total number of permanently-displaced persons (PDP) can be estimated by multiplying 'number of permanently displaced households' by "average number of person per household'. Statistics on population and housing census released by the National Population Commission (NPC) (2006) estimated the average household size for Oyo State at 6 persons per household. Thus, PDP $=621 \times 6=3,726$. This implies that about 3,726 persons were permanently displaced. The major limitation to this computation is that this figure considers only households that left the abandoned buildings. It failed to include households (who were mostly tenants) that relocated even when their initial homes were still inhabited.

Cases of abandonment significantly varied directly with the level of impact of flood disaster across the affected areas $(r=0.673)$. This implies is that level of impact of flooding as is reflected in the number of affected buildings influences the rate of abandonment. 


\subsection{SOCIOECONOMIC DETERMINANTS OF FLOOD-INDUCED DISPLACEMENT}

According to Ferris (2011), individuals and households make decisions on the basis of the perceived risk of staying where they are, analysis of possibilities for settlement elsewhere, and available resources for making the move. However, these decisions are rooted in circumstances that can be linked to the socioeconomic attributes of floodaffected persons and households. This study revealed significant differences in the number of households that abandoned their dwellings across age groups ( $x 2=37.171, p=0.001)$, across education level $(x 2=51.067, p=0.000)$ and according to occupation $(X 2=88.075$, $p=0.000$ ). The higher the age group, the longer the period of displacement. Civil servants and private practitioners were displaced for a longer period than farmers, traders and artisans. However, flood-induced displacement was the same across marital status of respondents $(x 2=23.888, p=0.067)$.

Furthermore, cases of abandonment of buildings differed significantly according to income groups ( $x 2=81.883$, $p=0.000$ ) and there was a positive variation between income of $\mathrm{HH}$ heads and building abandonment $(r=0.258$, $p=0.001$ ). It was observed that cases of permanent relocation was more among high income earners. In the same vein, low-income earners stayed back at their flood-prone buildings, even after the flood event.

Building use is another factor that affected flood-induced displacement. There was a significant difference in cases of floodinduced displacement across building uses $(x 2=117.395, p=0.000)$. During an interview session with a community leader in Ona-Ara LGA, it was revealed that occupants of non-residential buildings, such as schools, places of worship and shops, were quick to return to the buildings after the flooding. It was argued that flooding pose greater threat to life in residential buildings than other building uses because people sleep in residential buildings overnight. If a flood event should happen while occupants are asleep in the night, evacuation and rescue activities would be slow and difficult.

The period of displacement was compared across status of building occupancy. It was observed that owneroccupier buildings were abandoned for longer periods than rental housing. The differences across building occupancy was significant $(x 2=39.456, p=0.001)$. Conversely, there was no significant difference in the period of flood-induced displacement and the number of storeys of building ( $x 2=21.057, p=0.135)$.

\subsection{DISPARITIES IN RESCUE ACTIVITIES AND RELIEF ITEM DISTRIBUTION}

The nature of help and support rendered to vulnerable households during and after the flood varied according to affected communities and LGAs. The rescue services rendered by emergency response institutions - the Civil Defence Corp, Fire Service, OYOSEMA, the NRCS, Religious Organizations, NGOs, Police and Community Groups - was not even across the flood-affected areas. The main reasons given for this include: inaccessibility to some affected communities during flooding, inadequate staff strength, inadequate working materials and insufficient funds. For instance, during the 26 August, 2011 flood event, the Fire Service were only able to assist in three LGAs including Oluyole, Ibadan North and Ibadan South-West LGA. Apete community in particular was isolated when the bridge was washed away by flood. This prevented the rescue team from carrying out necessary support to the affected households. This confirms

Relief packages were distributed to victims of flood disaster by the emergency management agencies. The Oyo state government's assistance in the form of relief materials were distributed via the OYOSEMA. The relief materials were grouped into three - food items, household goods and building materials. Food items distributed include rice, beans, garri (cassava flour) and maize; household goods distributed include mattress, blanket, bucket, bundles of six yard wax, towel, and mat; and the building materials distributed include bags of cement, packs of nails and bundles of iron roofing sheets.

The pattern of distribution of relief items to the urban area and sub-urban area in three consecutive years was analysed. In the urban area, consisting of five local governments (Ibadan North, Ibadan North-East, Ibadan North-West, Ibadan South-East and Ibadan South-West), more food items were distributed. More of all the relief items went to the urban with the exception of mats and roofing sheets. A paired-sample t-test model showed significant difference in urban and sub-urban communities' access to relief items in year 2011 ( $\mathrm{t}=2.504$, $\mathrm{p}=0.026)$ and in 2012 ( $\mathrm{t}=-2.697, \mathrm{p}=$ 0.018). This confirms investigations carried out by ALNAP and ProVention (2008) which revealed disparities between rural and urban areas in recovery activities. Households that falls within the urban areas benefited more from government's relief package than those within sub-urban areas. This is because urban dwellers tend to be more politically powerful and vocal in pursuing relief materials and emergency allocations, even when the damage is more severe in rural areas and poverty is also concentrated there.

\section{CONCLUSION AND RECOMMENDATIONS}

A considerable proportion of the displaced households were connected with fear of flood recurrence. Vulnerable households that had no better place to go continued to live in damaged homes or in makeshift shelters or temporary sites in vulnerable areas. The paper argues that to overcome the major challenges being faced by the urban poor, the migrants, children and women and other vulnerable groups in most African cities, we must have a critical re-think on the discriminatory approach by which our cities are presently governed and fashion out a new framework for equitable provision and access to urban amenities and resources based on participatory, collaborative, and consensual decisionmaking, grounded in inclusiveness and sustainability.

The vulnerable groups are critical stakeholders in the business of sustainable city governance and possess very rich indigenous knowledge 
that evolved through the citizen science and can be employed to adequately address the physical, social, economic and other dimensions of vulnerability and create cities that are inclusive of all class and groups.

The proposed Resettlement Policy Framework (RPF), sponsored by the World Bank was expected to be a relief for the flood-affected households and persons living in flood prone areas but the implementation has not lived to the expectation. The Policy Framework describes the process and methods for carrying out resettlement under the Project, including compensation, relocation and rehabilitation of project-affected persons. However, considering that the Ibadan Urban Flood Management Project (IUFMP) has been on for close to a decade and the details of the subprojects are clear, there is still no clear direction on sustainable flood management in Ibadan. On this note, the need to protect the immediate environment, the human population and livelihoods from recurrence of unmitigated flood disasters should be embedded in a programme of actions adopted by the governments at all levels as well as NGOs. There is also the need to go beyond distribution of relief items to more empowering programmes for the most vulnerable groups.

The Sustainable Ibadan Project (SIP) is a demonstration city project for Nigeria launched in 1995 and jointly funded by the UNCHS (Habitat), Oyo State Government, and the eleven (11) Local Governments in Ibadan region to rid the city of its environmental problems. The SIP employed the Environmental Planning and Management (EPM) Framework through which the citizens and all stakeholders were involved in participatory planning and more efficient management of the process of urban development. The EPM framework was adopted in addressing the very poor water supply situation in Oke-Offa Babasale, a high-density, low-income residential community in Ward 10, Ibadan North-East local government area where women and children (ages 8 to 16 years old) spent hours looking for water, and experiencing a high incidence of waterborne diseases, typhoid fever, and cholera (Odo-Akeu Spring Water
Development Project Working Group 1996; SIP-TSU 2015). The process of collaboration and integration evolved which involved the Oke-Offa Babasale Community leaders, the Sustainable Ibadan Project-Technical Support Unit, and representatives of Oyo State Department of Rural Development, Ibadan North-East LG Council, UNICEF, academia, and the private sector. The collaboration ensured an equal partnership, based on consensus, in critical decision-making. Each side contributed time, material, financial resources, and human resources, though in varying proportions. The water project demonstrated how the urban poor and vulnerable groups can be integrated into urban facility planning and management to enhance the quality of a communitybased water resource, to increase a community's access to potable water, and to promote sustainable water delivery. The project experienced some challenges from the integration process, but these were resolved using the extant indigenous approaches to conflict resolution within the community. 


\section{REFERENCES}

ADPC, UNDP: Integrated flood risk management in Asia. Bangkok: Asian Disaster Preparedness Center and United Nations Development Programme. (2005).

Akintola, F.: Geology and Hydrology. In: Filani M., Akintola, F., Ikporukpo, C. (eds.), Ibadan Region. Ibadan: Rex Charles Publications (1994).

Adedeji, O., Odufuwa, B., Adebayo O.: Building Capabilities for Flood Disaster and Hazard Preparedness and Risk Reduction in Nigeria: Need for Spatial Planning and Land Management. Journal of Sustainable Development in Africa, 14(1), 1-15 (2012).

ALNAP, ProVention: Flood disasters: Learning from previous relief and recovery operations. (2008). Available at (Retrieved in June, 2012) www.alnap.org/publications/pdfs/ ALNAPProVention_lessons_on_Flood_ disasters.pdf

Agbola, T., Alabi, M. Planning Laws, Building standards and the Politics of Illegality in Human settlements: A case study from Ibadan, Nigeria. (2009).

Schneider, S. H., Semenov, S., Patwardhan, A., Burton, I., Magadza C. H. D., Oppenheimer, M., Pittock, A. B., Rahman, A., Smith, J. B., Suarez, A., Yamin, F. (2007). Assessing Key Vulnerabilities and the Risk from Climate Change. In: Parry, M. L., Canziani, O. F., Palutikof, J. P., Linden, P. J., Hanson, C. E. (eds), Climate Change 2007: Impacts, Adaptation and Vulnerability. Contribution of Working Group II to the Fourth Assessment Report of the Intergovernmental Panel on Climate Change, Cambridge: Cambridge University Press , pp 779-810.

Lavell, A., (2003). Local Level Risk Management: Concept and Practices. Quito: CEPREDENAC- UNDP.

Cutter, S. L., Boruff, B. J. \& Shirley, W. L. (2003). "Social Vulnerability to Environmental Hazards”. Social Science Quarterly 84 (2), pp. 242-261.
Bankoff, G., (2004). The Historical Geography of Disaster: 'Vulnerability' and 'Local Knowledge' in Western Discourse. London: Earthscan.

DEC (2000). Bangladesh 1998 Flood Appeal - An independent evaluation. Final report. London: Disasters Emergency Committee. Available at apps.odi.org.uk/erd/ReportDetail. aspx?reportID=2859 (Retrieved in April, 2012)

Kent, H. (2004). Linkages between flood and drought disasters in Cambodia and rural livelihood and food security. International Federation of Red Cross and Red Crescent Societies and the Cambodian Red Cross Society.

Zevenbergen, C. (2007). Adapting To Change: Towards Flood Resilient Cities. Inaugural Address by Chris Zevenbergen in Delft, the Netherlands. UNESCO-IHE (Institute for Water Education)

Alam, K. et al. (2007b). Drowning Sand and the Holy Banana Tree: The tale of people with disability and their neighbors coping with Sharbanasha floods in the Brahmaputra-Jamuna Chars of Bangladesh. Dhaka: Handicap International.

DipECHO (2004). "The Evaluation of DIPECHO Action Plans in the Caribbean Region" Brussels: Directorate-General for Humanitarian Aid Disaster Preparedness Programme. apps.odi.org.uk/erd/ReportDetail. aspx?reportID=3276

IFPRI (2001). The 1998 Floods in Bangladesh Disaster Impacts, Household Coping Strategies, and Response. Washington DC: International Food Policy Research Institute.www.ifpri.org/pubs/abstract/ abstr122.htm
World Bank (2005). Learning

Lessons from Disaster Recovery:

The Case of Mozambique. Disaster Risk Management Working Paper Series No. 11. Washington DC: World Bank.www.proventionconsortium. org $/$ pageid $=37$ publicationid $=40 \# 40$

Oyo State Government: Government of Oyo State Report on the Assessment of the 26th August 2011 Flood Disaster in Ibadan Metropolis. Oyo State

Task Force on Flood Prevention and Management, Ibadan (2011).

National Population Commission (NPC): Total population by Administrative level, Gender and Year. NPC, Abuja (2010).

Ferris, E.: Planned relocations, disasters and climate change. (2011). Retrieved from http://www.gtcentre. unsw.edu.au/sites/gtcentre.unsw.edu. au/files/Elizabeth\%20Ferris\%20paper. pdf (Accessed 30 May 2014).

Odo-Akeu Spring Water Development Project Working Group. Proposal for Technical and

Financial Assistances for the Development of Odo-Akeu Spring Water at Babasale in Ibadan North-East Local Government. Unpubl. Report by SIP Technical Support Unit. (1996).

SIP-TSU. Executive Summary on OdoOsun Natural Spring Project at OkeOffa Babasale, Ibadan, in Ibadan NorthEast Local government area of Oyo State. Unpubl. Report by SIP Technical Support Unit. (2015). 
Notes 